\title{
PENGARUH PUPUK ORGANONITROFOS, PUPUK NPK DAN KOMBINASINYA TERHADAP POPULASI, PRODUKSI, DAN HARA TERANGKUT C, N, P TANAMAN TEBU (Saccharum Officinarum L.) RATOON 2 DI TANAH ULTISOL GEDUNG MENENG
}

\section{THE INFLUENCE OF ORGANONITROPHOS FERTILIZER, NPK FERTILIZER AND ITS COMBINATIONS ON POPULATION, PRODUCTION, AND TRANSPORTED NUTRIENTS OF C, N, P CANE PLANTS (Saccharum officinarum L.) RATOON 2 IN ULTISOL SOIL OF GEDUNG MENENG}

\author{
Akbar Hamzah*, Jamalam Lumbanraja, Supriatin, Sarno, Riajeng Hanum Amalia, \\ Catur Putra Satgada, Eldineri Zulkarnain, Tegar Rafshodi Awang dan Wiwik Agustina \\ Jurusan Agroteknologi, Fakultas Pertanian Universitas Lampung, Bandarlampung, Indonesia \\ Email: akbarhamzah235813@gmail.com
}

* Corresponding Author, Diterima: 10 Okt. 2021 , Direvisi: 27 Okt. 2021 , Disetujui: 30 Des. 2022

\section{ABSTRACT}

\begin{abstract}
The increase in sugarcane production was hampered by low levels of organic matter and macro nutrients $N$, $P, K, C a$ and $\mathrm{Mg}$ in Utisol soils. Because in Ultisol soil the Al ${ }^{3+}$ content is quite high, and the base saturation is low. The addition of organonitrofos and inorganic fertilizers is one way to overcome this. This study aimed to determine the influence of the combination of organonitrofos and NPK fertilizers on production, population, and transported nutrients and transported nutrients of ratoon 2 sugarcane, and and the correlation between total $N$-soil and P-available soil with $N$ and $P$ absorbed by sugarcane plants. ratoon 2. This study consisted of 5 treatments and 3 replications, arranged in a randomized block design (RBD). The treatments consisted of: A. 100\% NPK (300 kg ha-1 urea, $\left.150 \mathrm{~kg} \mathrm{ha}^{-1} \mathrm{TSP}, 300 \mathrm{~kg} \mathrm{ha}{ }^{-1} \mathrm{KCl}\right), \mathrm{B} .100 \%$ organonitophos (10,000 kg ha-1 organonitrofos), C. 100\% NPK +50\% organonitrofos $\left(300 \mathrm{~kg} \mathrm{ha}^{-1}\right.$ urea, $150 \mathrm{~kg} \mathrm{ha}^{-1} \mathrm{TSP}$, $300 \mathrm{~kg} \mathrm{ha}^{-1} \mathrm{KCl}, 5000 \mathrm{~kg} \mathrm{ha} a^{-1}$ organonitrofos), D. $50 \% \mathrm{NPK}+100 \%$ organonitrofos (150 kg ha-1 urea, $75 \mathrm{~kg}$ $h a^{-1} T S P, 150 \mathrm{~kg} \mathrm{ha}{ }^{-1} \mathrm{KCl}, 10,000 \mathrm{~kg} \mathrm{ha} a^{-1}$ organonitrofos), and E. without fertilization. The results showed that the application of inorganic NPK fertilizers, organonitrofos fertilizers and their combinations had a significant effect on the production and transported nutrients of $C, N, P$ ratoon 2 sugarcane plants, but did not significantly affect the ratoon 2 sugarcane plant population. $100 \%$ NPK, $50 \%+100 \%$ organonitrofos provided production and transported nutrients of $C, N, P$ sugarcane plants which were not significantly different, but significantly higher than the $100 \%$ organonitrofos treatment and without fertilization. There is a positive correlation of $N$-total soil and $P$-available with $N$ and $P$ absorbed by ratoon 2 sugarcane, so that the total N-soil content and P-available soil determine the amount of $N$ and $P$ that can be absorbed by ratoon 2 sugarcane plants.
\end{abstract}

Keywords: Fertilizer, organonitrofos, ratoon sugarcane, ultisols.

\begin{abstract}
ABSTRAK
Peningkatan produksi tebu banyak terkendala seperti rendahnya bahan organik dan hara makro N, P, K, Ca, dan $\mathrm{Mg}$ di tanah ultisol. Karena di tanah ultisol kandungan kadar $\mathrm{Al}^{3+}$ yang cukup tinggi, dan kejenuhan basa yang rendah. Penambahan pupuk organonitrofos dan anorganik merupakan salah satu cara untuk mengatasi hal ini. Penelitian ini bertujuan untuk mengetahui pengaruh kombinasi pupuk organonitrofos dan pupuk NPK terhadap produksi, populasi, dan hara terangkut dan hara terangkut tanaman tebu ratoon 2, dan korelasi antara N-total tanah dan P-tersedia tanah dengan $\mathrm{N}$ dan $\mathrm{P}$ yang diserap oleh tanaman tebu ratoon 2. Penelitian ini terdiri 5 perlakuan dan 3 ulangan, disusun dalam Rancangan Acak kelompok (RAK). Perlakuan terdiri dari: A. 100\% NPK (300 kg ha-1 urea, $\left.150 \mathrm{~kg} \mathrm{ha}^{-1} \mathrm{TSP}, 300 \mathrm{~kg} \mathrm{ha}^{-1} \mathrm{KCl}\right)$, B. $100 \%$ organonitofos (10.000 kg ha-1 organonitrofos), C. $100 \% \mathrm{NPK}+50 \%$ organonitrofos ( $300 \mathrm{~kg} \mathrm{ha}^{-1}$ urea, $150 \mathrm{~kg} \mathrm{ha}^{-1} \mathrm{TSP}, 300 \mathrm{~kg} \mathrm{ha}^{-1} \mathrm{KCl}, 5000 \mathrm{~kg} \mathrm{ha}^{-1}$ organonitrofos), D. $50 \% \mathrm{NPK}+100 \%$ organonitrofos $\left(150 \mathrm{~kg} \mathrm{ha}^{-1}\right.$ urea, $75 \mathrm{~kg} \mathrm{ha}^{-1} \mathrm{TSP}, 150 \mathrm{~kg} \mathrm{ha}^{-1} \mathrm{KCl}, 10.000 \mathrm{~kg} \mathrm{ha}$ organonitrofos), dan E. tanpa pemupukan. Hasil penelitian menunjukkan bahwa Pemberian pupuk anorganik
\end{abstract}


NPK, pupuk organonitrofos dan kombinasi berpengaruh nyata terhadap produksi dan hara terangkut C, N, P tanaman tebu ratoon 2 , namun tidak berpengaruh nyata terhadap populasi tanaman tebu ratoon 2 . Pemberian $100 \%$ NPK, $50 \%$ NPK $+100 \%$ organonitrofos $100 \%$ NPK $+50 \%$ organonitrofos dan memberikan produksi dan hara terangkut $\mathrm{C}, \mathrm{N}, \mathrm{P}$ tanaman tebu yang tidak berbeda nyata, namun nyata lebih tinggi dibandingkan dengan perlakuan $100 \%$ organonitrofos dan tanpa pemupukan. Korelasi positif N-total tanah dan P-tersedia dengan $\mathrm{N}$ dan $\mathrm{P}$ yang diserap oleh tanaman tebu ratoon 2, sehingga kandungan $\mathrm{N}$-total tanah dan P-tersedia tanah menentukan jumlah $\mathrm{N}$ dan $\mathrm{P}$ yang dapat diserap oleh tanaman tebu ratoon 2.

Kata kunci:, Organonitrofos, pupuk, tebu ratoon, ultisol.

\section{PENDAHULUAN}

Tebu merupakan salah satu komoditas perkebunan penting di Indonesia karena dijadikan sebagai bahan baku utama produksi gula. Tanaman tebu juga merupakan salah satu tanaman yang berperan penting dalam perekonomian Indonesia. Salah satu upaya mengatasi kebutuhan gula diperlukan peningkatan produktivitas tebu. Terdapat dua cara untuk meningkatkan produksi tebu yaitu, ekstensifikasi berupa perluasan areal penanaman tebu dan intensifikasi seperti pengelolaan lahan, penggunaan benih unggul, perawatan tanaman, dan pemupukan. Berdasarkan data statistik Direktorat Jenderal Perkebunan (2017), produktivitas gula nasional mencapai 5,6 ton $\mathrm{ha}^{-1}$ pada tahun 2015 , dan mengalami kenaikan menjadi 5,7 ton $\mathrm{ha}^{-1}$ pada tahun 2016. Sementara produktivitas gula nasional mengalami penurunan menjadi 5,4 ton $\mathrm{ha}^{-1}$ pada tahun 2017. Sehingga hal ini mempengaruhi produksi gula nasional mencapai 2,53 juta ton pada tahun 2015. Kemudian produksi gula nasional terus mengalami penurunan menjadi 2,36 juta ton dan 2,19 juta ton pada tahun 2016 dan 2017. Hal ini juga dipengaruhi oleh luasan areal tebu yang mengalami penurunan luas, karena areal tebu di Indonesia sebesar 454,17 ribu hektar pada tahun 2015 luas, namun terjadi penurun menjadi 445,52 ribu pada tahun 2016. Tetapi mengalami peningkatan menjadi 453,45 ribu hektar pada tahun 2017.

Selain masalah areal yang mengalami penurunan luas, penggunaan pupuk anorganik secara terus menerus membuat kualitas tanah pada lahan pertanaman tebu menurun. Selain itu, peningkatan produksi tebu yang umumnya ditanam pada tanah Ultisol banyak terkendala akibat rendahnya bahan organik dan hara makro $\mathrm{N}, \mathrm{P}, \mathrm{K}$, $\mathrm{Ca}$, dan $\mathrm{Mg}$ di tanah Ultisol, serta kandungan kadar $\mathrm{Al}^{3+}$ yang cukup tinggi, dan kejenuhan basa yang rendah (Hardjowigeno, 2003). Hal tersebut diduga menjadi penyebab turunnya produktivitas tebu nasional. Dengan demikian, cara intensifikasi seperti pemberian pupuk organik yang dikombinasikan dengan pupuk anorganik perlu dilakukakan untuk meningkatkan produksi tebu. Pemberian pupuk organik yang dikombinasikan dengan pupuk anorganik yang cukup dapat memperbaiki kesuburan tanah. Pupuk organik berperan penting dalam perbaikan sifat kimia, fisika, dan biologi tanah serta sebagai sumber nutrisi tanaman. Secara umum kandungan hara dalam pupuk organik tergolong rendah dan agak lambat tersedia, sehingga diperlukan dalam jumlah yang cukup banyak. Salah satu jenis pupuk organik yang dapat digunakan adalah pupuk organik organomineral NP (organonitrofos).

Penelitian ini bertujuan untuk mengetahui kombinasi dosis pupuk organonitrofos dan pupuk NPK yang memiliki pengaruh paling efektif terhadap populasi, produksi, dan hara terangkut tanaman tebu ratoon 2, dan mengetahui hubungan $\mathrm{N}$-total tanah dan P-tersedia tanah dengan $\mathrm{N}$ dan $\mathrm{P}$ yang diserap oleh tanaman tebu ratoon 2 .

\section{BAHAN DAN METODE}

Penelitian yang dilakukan yaitu penelitian lanjutan dari penelitian sebelumnya yang mempelajari tentang pengaruh kombinasi pupuk organik dan anorganik NPK pada pertanaman plant cane pada bulan Agustus 2014 sampai September 2015 dan ratoon 1 pada bulan September 2015 sampai dengan September 2016 di Laboratorium Lapang Terpadu Universitas Lampung dan analisis tanah tanaman di Laboratorium Ilmu Tanah Universitas Lampung.

Penelitian tanaman tebu ini dilaksanakan menggunakan Rancangan Acak Kelompok (RAK) terdiri dari 5 perlakuan dengan tiga kelompok. Data populasi tanaman, bobot brangkasan segar, bobot brangkasan kering dan hara terangkut $\mathrm{C}, \mathrm{N}$, dan $\mathrm{P}$ diuji homogenitas ragam dengan uji Barlet, aditivitas data dengan uji Tukey. Pengaruh dari seluruh perlakuan diuji menggunakan uji $\mathrm{F}$ dilanjutkan analisis ragam dan uji Beda Nyata Terkecil (BNT). 
Sedangkan untuk mengetahui hubungan $\mathrm{N}$ dan $\mathrm{P}$ di dalam tanah dan hara terangkut $\mathrm{N}$ dan $\mathrm{P}$ pada tanaman tebu dilakukan uji korelasi. Daftar perlakuan yang dilakukan meliputi: A. 100\% NPK (Urea: $300 \mathrm{~kg} \mathrm{ha}^{-1}$; TSP: $150 \mathrm{~kg} \mathrm{ha}^{-1}$; KCl: $300 \mathrm{~kg}$ $\mathrm{ha}^{-1}$ ), B:100\% organonitrofos (Organonitrofos: $\left.10.000 \mathrm{~kg} \mathrm{ha}^{-1}\right)$, C. $100 \% \mathrm{NPK}+50 \%$ organonitrofos (Urea: $300 \mathrm{~kg} \mathrm{ha}^{-1}$; TSP: $150 \mathrm{~kg} \mathrm{ha}^{-}$ ${ }^{1} ; \mathrm{KCl}: 300 \mathrm{~kg} \mathrm{ha}^{-1}$; Organonitrofos: $5000 \mathrm{~kg} \mathrm{ha}^{-1}$ ), D. $50 \% \mathrm{NPK}+100 \%$ organonitrofos (Urea: 150 kg ha ${ }^{-1}$; TSP: $75 \mathrm{~kg} \mathrm{ha}^{-1}$; KCl: $150 \mathrm{~kg} \mathrm{ha}^{-1}$; Organonitrofos: $10.000 \mathrm{~kg} \mathrm{ha}^{-1}$ ) dan E.Tanpa Pemupukan.

Analisis tanah yang dilakukan yaitu: C-organik (Walkey dan Black), N-total (metode Kjeldhal), dan P-tersedia (metode Bray ${ }^{-1}$ ). Sementara itu, analisis C (metode Walkey dan Black) dan N (metode Kjeldahl) jaringan tanaman langsung pada sampel tanaman yang telah dihaluskan dan analisis $\mathrm{P}$ (metode blue molibdenum) jaringan tanaman dilakukan harus diabukan terlebih dahulu pada suhu $300^{\circ} \mathrm{C}$ selama dua jam, lalu suhu dinaikkan hingga $400^{\circ} \mathrm{C}$ selama empat jam (Thom dan Utomo, 1991).

\section{HASIL DAN PEMBAHASAN}

\subsection{Sifat Kimia Tanah Sebelum Panen dan Setelah Panen Tanaman Tebu Ratoon 2}

Hasil analisis kimia tanah sebelum panen dan setelah panen tanaman tebu ratoon 2 menunjukkan bahwa perlakuan pupuk anorganik NPK, pupuk organonitrofos dan kombinasinya, yang meliputi perlakuan A (100 \% NPK), B (100\% Organonitrofos), C (100\% NPK $+50 \%$ Organonitrofos), dan D (50\% NPK $+100 \%$ Organonitrofos) mampu mempertahankan kandungan $\mathrm{N}$-total tanah, dimana semua kandungan $\mathrm{N}$-total tanah tergolong sedang (Tabel 1). Kandungan $\mathrm{N}$-total tanah tersebut dapat dipertahankan dari pertanaman ratoon 1 hingga ratoon 2 karena penambahan pupuk organonitrofos atau kombinasinya dengan pupuk anorganik NPK. Pada perlakuan E ( tanpa pemupukan) kandungan $\mathrm{N}$-total tanah setelah panen tergolong rendah dibandingkan dengan $\mathrm{N}$-total tanah sebelum panen yang tergolong sedang.

Hasil penelitian ini didukung oleh pernyataan Nugroho, dkk., (2012) bahwa salah satu komposisi utama pupuk organonitrofos adalah $80 \%$ kotoran sapi dan ditambah mikroba penambat N. Selain itu, kandungan $46 \% \mathrm{~N}$ di dalam pupuk Urea juga menjadi faktor bertahannya kandungan N-total tanah. Sedangkan $\mathrm{N}$-total tanah pada perlakuan E (tanpa pemupukan) tergolong rendah yang diduga karena tidak adanya bahan organik tambahan yang diberikan selama proses budidaya. Hal ini didukung oleh pernyataan Reijntjes, dkk., (1992) bahwa tanpa dilakukan pemberian pupuk produksi tanaman hanya tergantung pada jumlah hara yang disediakan oleh tanah, yang ditambahkan oleh hujan dan endapan debu.

Sebelum panen, P-tersedia tanah pada perlakuan $\mathrm{E}$ (tanpa pemupukan) tergolong rendah, sedangkan pada perlakuan A (100\% NPK), B (100 $\%$ Organonitrofos), D (50\% NPK $+100 \%$ Organonitrofos) tergolong sedang dan pada perlakuan C (100\% NPK + 50\% Organonitrofos), tergolong tinggi (Tabel 1). Setelah panen, P-tersedia tanah pada perlakuan pupuk anorganik NPK dan kombinasinya dengan pupuk Organonitrofos, yaitu pada perlakuan A (100\% NPK), C (100\% NPK + $50 \%$ Organonitrofos), D (50\% NPK $+100 \%$ Organonitrofos) tergolong sedang. Hal ini diduga

Tabel 1. Kandungan unsur hara tanah sebelum panen (awal) dan setelah panen (akhir) pada pertanaman tebu ratoon 2.

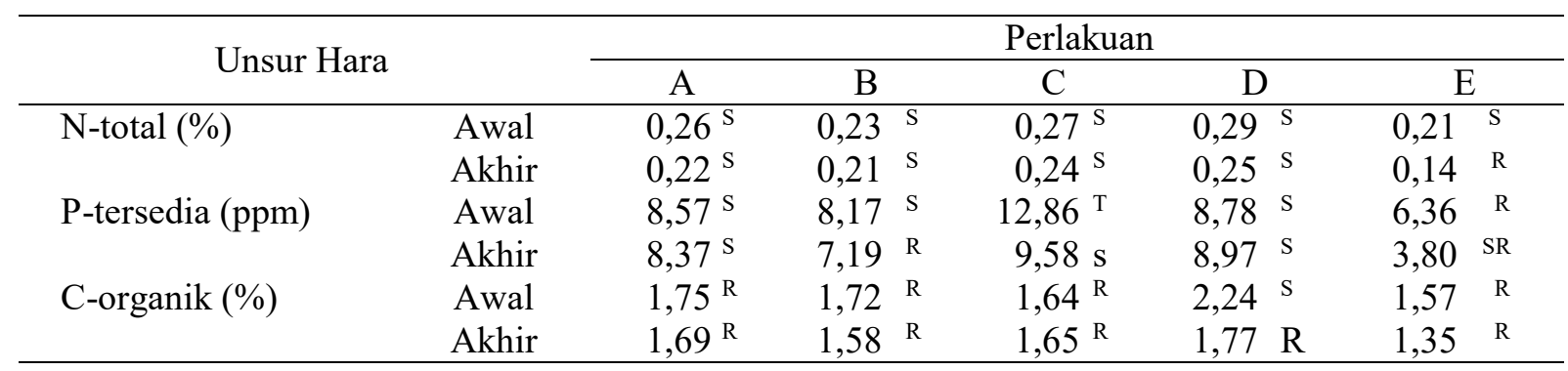

Keterangan: A. $100 \%$ NPK; B. $100 \%$ Organonitrofos; C. 100\% NPK + 50\% Organonitrofos; D. 50\% NPK + 100\% Organonitrofos; E. Tanpa Pemupukan. Angka yang diikuti huruf menyatakan $\mathrm{S}=$ sedang; $\mathrm{T}=$ tinggi; $\mathrm{R}=$ rendah; $\mathrm{SR}=$ sangat rendah (Eviati dan Sulaeman, 2009). 
berasal dari residu pupuk $\mathrm{P}$ yang diberikan di awal pertumbuhan tanaman tebu ratoon 2. Loks, dkk., (2014) melaporkan bahwa pemberian pupuk P memiliki efisiensi yang rendah karena pupuk $P$ yang diberikan tidak memberikan pengaruh secara langsung pada tanaman. Oleh sebab itu pupuk yang diberikan ke dalam tanah tidak diserap keseluruhan oleh tanaman namun banyak yang terjerap oleh koloid tanah.

Pada perlakuan B (100\% Organonitrofos), dan E (tanpa pemupukan) kandungan P-tersedia tanah tergolong rendah dan sangat rendah karena tidak adanya penambahan pupuk anorganik pada tanaman. Menurut Satgada (2017), penurunan P tersedia di dalam tanah dapat disebabkan oleh penyerapan unsur hara $\mathrm{P}$ oleh tanaman tebu yang tinggi pada fase vegetatif dan generatif. Laju dekomposisi bahan organik yang tinggi juga dapat menyebabkan kandungan $P$ tersedia di dalam tanah pada setiap perlakuan menurun. Hal ini menunjukkan bahwa kandungan $P$ tersedia di dalam tanah sangat dipengaruhi oleh kandungan bahan organik pada tanah tersebut. Jika kandungan bahan organik dalam suatu tanah tinggi maka kandungan $P$ tersedia di dalam tanah juga akan tinggi (Utami dan Handayani, 2003).

Kandungan C-organik tanah sebelum panen pada perlakuan A(100\% NPK), B (100 \% Organonitrofos), C $(100 \%$ NPK $+50 \%$ Organonitrofos $), D(50 \%$ NPK $+100 \%$ Organonitrofos), dan E (tanpa perlakuan) tergolong rendah. Setelah panen, kandungan Corganik tanah pada masing-masing perlakuan tersebut masih tergolong rendah. Hal ini sejalan dengan hasil penelitian Amalia (2017) yang menunjukkan bahwa kandungan C-organik pada lahan pertanaman tebu pertama (plant cane) yang dikan pupuk anorganik NPK dan pupuk organonitrofos atau kombinasinya tergolong rendah dengan rata-rata $1,65 \%$ pada tanah awal (sebelum panen) dan 1,49\% pada tanah akhir (setelah panen).
Hal ini juga didukung oleh hasil penelitian Nurhidayat (2018) dimana kandungan C-organik pada lahan pertanaman tebu ratoon 1 yang dikan pupuk anorganik NPK dan pupuk organonitrofos atau kombinasinya tergolong rendah. Kandungan C-organik rata-rata tanah awal (sebelum panen) $1,49 \%$ yang tergolong rendah dan pada tanah akhir (setelah panen) 1,78\% yang juga tergolong rendah.

\subsection{Pengaruh Pupuk Anorganik NPK, Pupuk Organonitrofos dan Kombinasinya terhadap Populasi Tanaman Tebu Ratoon 2}

Data pada Tabel 2 menunjukkan bahwa perlakuan D (50\% NPK + 100\% Organonitrofos) menghasilkan populasi tanaman tebu ratoon 2 tertinggi, namun tidak berbeda nyata dengan populasi tanaman tebu pada perlakuan A $(100 \%$ NPK), B (100\% Organonitrofos), C (100\% NPK $+50 \%$ Organonitrofos), dan E (Tanpa Pemupukan). Hasil pada Tabel 2 menunjukkan bahwa populasi tanaman tebu pada perlakuan E (tanpa pemupukan) paling rendah dibandingkan perlakuan pupuk anorganik NPK, pupuk organonitrofos atau kombinasi kedua pupuk tersebut. Hal ini diduga karena dalam penelitian ini pada perlakuan E tidak dilakukan pemberian pupuk yang membuat tanaman kehilangan kemampuan untuk memproduksi banyak batang karena kandungan dan ketersediaan unsur hara yang terbatas.

Hasil penelitian Zulkarnain dkk. (2017) dan Nurhidayat (2018) menunjukkan bahwa pemberian $100 \%$ NPK $+50 \%$ Organonitrofos, $50 \%$ NPK + $100 \%$ organonitrofos, $100 \%$ Organonitrofos, dan $100 \%$ NPK menghasilkan populasi tanaman tebu plant cane dan ratoon 1 yang tidak berbeda nyata tetapi lebih tinggi dan berbeda nyata dengan populasi tanaman tebu pada perlakuan tanpa pemupukan.

Tabel 2. Pengaruh Pupuk Anorganik NPK, Pupuk Organonitrofos dan Kombinasinya terhadap Populasi Tanaman Tebu Ratoon 2.

\begin{tabular}{lc}
\hline \multicolumn{1}{c}{ Perlakuan } & Populasi $\left(\right.$ Batang ha $\left.^{-1}\right)$ \\
\hline $100 \%$ NPK & 73500 \\
$100 \%$ Organonitrofos & 72000 \\
$100 \%$ NPK $+50 \%$ Organonitrofos & 71333 \\
$50 \%$ NPK $+100 \%$ Organonitrofos & 74500 \\
Tanpa Pemupukan & 58833 \\
\hline Uji F & tn \\
\hline
\end{tabular}

Keterangan: $\mathrm{tn}=$ tidak nyata 


\subsection{Pengaruh Pupuk Anorganik NPK, Pupuk Organonitrofos dan Kombinasinya terhadap Bobot Basah, Produktivitas dan Bobot Kering Tanaman Tebu Ratoon 2}

\subsubsection{Bobot basah tanaman tebu}

Tabel 3 menunjukkan bahwa bobot basah total tanaman tebu pada perlakuan A (100\% NPK), B (100\% Organonitrofos), C (100\% NPK + 50\% Organonitrofos), D (50\% NPK $+100 \%$ Organonitrofos) tidak berbeda nyata, namun lebih tinggi dibandingkan pada perlakuan E (tanpa pemupukan). Bobot basah total tanaman tebu pada perlakuan E paling rendah.

Hasil tersebut di atas menunjukan bahwa pemberian pupuk NPK maupun kombinasinya dengan pupuk organitrofos dapat meningkatkan bobot basah total tanaman tebu. Hasil penelitian Satgada (2017) juga menunjukkan bahwa pemberian $100 \% \mathrm{NPK}+50 \%$ Organonitrofos , dan $100 \%$ NPK menghasilkan bobot basah total tertinggi, namun tidak berbeda nyata antar perlakuan tersebut. Hal ini juga sejalan dengan hasil penelitian Nurhidayat (2018) yang menunjukan bahwa bobot basah total tanaman tebu ratoon 1 pada perlakuan $100 \% \mathrm{NPK} ; 100 \% \mathrm{NPK}+50 \%$ Organonitrofos; dan 50\% NPK $+100 \%$ Organonitrofos tidak berbeda nyata, namun lebih tinggi dan berbeda nyata dengan perlakuan $100 \%$ Organonitrofos dan tanpa pemupukan. Perlakuan tanpa pemupukan menghasilkan bobot basah total paling rendah.

\subsubsection{Produksi Tanaman Tebu}

Tabel 4 menunjukkan bahwa perlakuan A (100 $\%$ NPK) menghasilkan produksi tebu dan gula paling tinggi, namun tidak berbeda nyata dengan perlakuan B (100\% Organonitrofos), C (100\% NPK $+50 \%$ Organonitrofos) dan D (50\% NPK + $100 \%$ Organonitrofos). Hal ini sejalan dengan penelitian Zulkarnain dkk. (2017) dan Nurhidayat (2018) yang menunjukkan bahwa pemberian pemupukan NPK yang dikombinasikan dengan organonitrofos dapat meningkatan hasil produksi tebu dan gula.

Nilai rendemen merupakan faktor yang mempengaruhi produksi gula. Hasil rendemen tebu didapat dari penelitian Zulkarnain dkk. (2017), yang

Tabel 3. Pengaruh Pupuk Anorganik NPK, Pupuk Organonitrofos dan Kombinasinya terhadap Bobot Basah Tanaman Tebu Ratoon 2.

\begin{tabular}{|c|c|c|c|c|c|c|}
\hline \multirow{2}{*}{ Perlakuan } & \multicolumn{6}{|c|}{ Bobot Basah $\left(\mathrm{Mg} \mathrm{ha}^{-1}\right)$} \\
\hline & \multicolumn{2}{|c|}{ Batang } & \multicolumn{2}{|c|}{ Daun } & \multicolumn{2}{|c|}{ Total } \\
\hline $100 \% \mathrm{NPK}$ & 239,39 & $\mathrm{~b}$ & 17,19 & $\mathrm{bc}$ & 256,59 & $\mathrm{~b}$ \\
\hline $100 \%$ Organonitrofos & 123,92 & $a b$ & 10,97 & $a b$ & 134,91 & $a b$ \\
\hline $100 \%$ NPK $+50 \%$ Organonitrofos & 235,62 & $\mathrm{~b}$ & 17,69 & $\mathrm{c}$ & 253,31 & $\mathrm{~b}$ \\
\hline $50 \%$ NPK $+100 \%$ Organonitrofos & 240,17 & $\mathrm{~b}$ & 12,65 & $\mathrm{bc}$ & 252,82 & b \\
\hline Tanpa Pemupukan & 34,96 & $\mathrm{a}$ & 4,78 & $\mathrm{a}$ & 39,74 & $\mathrm{a}$ \\
\hline BNT 5\% & 98,93 & & 6,65 & & 98,5 & \\
\hline
\end{tabular}

Keterangan: Angka yang diikuti oleh huruf yang berbeda pada kolom yang sama menunjukkan perbedaan yang nyata pada taraf $5 \%$ uji BNT.

Tabel 4. Pengaruh Pupuk Anorganik NPK, Pupuk Organonitrofos dan Kombinasinya terhadap Produksi Tanaman Tebu Ratoon 2 dan Produksi Gula.

\begin{tabular}{|c|c|c|c|}
\hline Perlakuan & Rendemen $(\%)^{*}$ & $\begin{array}{l}\text { Produksi tebu } \\
\left(\mathrm{mg} \mathrm{ha}^{-1}\right)\end{array}$ & $\begin{array}{l}\text { Produksi gula } \\
\left(\mathrm{mg} \mathrm{ha}^{-1}\right)\end{array}$ \\
\hline $100 \%$ NPK & 8,05 & 239,39 b & $19,27 \mathrm{c}$ \\
\hline $100 \%$ Organonitrofos & 7,93 & 123,93 & 9,83 \\
\hline $100 \%$ NPK $+50 \%$ Organonitrofos & 7,47 & 235,62 & 17,60 \\
\hline $50 \%$ NPK $+100 \%$ Organonitrofos & 7,11 & 240,17 & 17,08 \\
\hline Tanpa Pemupukan & 7,03 & 34,96 a & 2,46 \\
\hline BNT 5\% & - & 98,93 & 7,24 \\
\hline
\end{tabular}

Keterangan: Angka yang diikuti oleh huruf yang berbeda pada kolom yang sama menunjukkan perbedaan yang nyata pada taraf 5\% uji BNT. *Zulkarnain dkk. (2017). 
menggunakan batang tanaman tebu plant cane segar. Kemudian batang tebu tersebut digiling untuk mendapatkan nira dan ampasnya. Nira yang didapatkan digunakan untuk mengetahui volume nira pada setiap satu batang tebu. Semakin besar volume nira yang dihasilkan dan didukung nilai rendemen yang tinggi maka akan meningkatkan produksi gula.

\subsubsection{Bobot kering tanaman tebu}

Hasil analisis ragam bobot kering batang, daun dan total tanaman tebu ratoon 2 menunjukkan bahwa pupuk organonitrofos, pupuk anorganik NPK dan kombinasinya berpengaruh nyata terhadap bobot kering batang, bobot kering daun, dan bobot kering total tanaman tebu ratoon 2 . Hal ini sejalan dengan hasil penelitian Agustina (2017) dan Satgada (2017) yang menunjukan bahwa pemberian pupuk anorganik NPK dan pupuk organonitrofos atau kombinasinya berpengaruh nyata terhadap bobot kering batang, dan bobot kering total tanaman tebu, namun tidak berpengaruh nyata terhadap bobot kering daun.

Tabel 5 menunjukkan bahwa perlakuan $\mathrm{C}$ $(100 \% \mathrm{NPK}+50 \%$ Organonitrofos) menghasilkan bobot kering batang paling tinggi, namun tidak berbeda nyata dengan perlakuan A (100\% NPK), D (50\% NPK + 100\% Organonitrofos), dan B (100\% Organonitrofos). Sedangkan untuk bobot kering total paling tinggi dihasilkan perlakuan $\mathrm{C}$ $(100 \% \mathrm{NPK}+50 \%$ Organonitrofos) namun tidak berbeda nyata dengan perlakuan A (100\% NPK), dan D (50\% NPK + 100\% Organonitrofos). Hasil penelitian Satgada (2017) dan Agustina (2017) juga menunjukkan bahwa kombinasi $100 \% \mathrm{NPK}+50 \%$ Organonitrofos menghasilkan bobot kering batang dan bobot kering total tanaman tebu paling tinggi dibandingkan perlakuan lainnya, namun tidak berbeda nyata dengan perlakuan $100 \%$ NPK. Hal ini juga sejalan dengan hasil penelitian Nurhidayat (2018) yang menunjukkan bahwa perlakuan $\mathrm{C}$ $(100 \%$ NPK $+50 \%$ Organonitrofos) menghasilkan bobot kering batang dan bobot kering total tanaman tertinggi, namun tidak berbeda nyata dengan perlakuan A (100\% NPK), dan D (50\% NPK + $100 \%$ Organonitrofos). Dengan demikian pemupukan yang disertai dengan penambahan pupuk NPK dan Organonitrofos belum dapat meningkatkan bobot kering tanaman tebu.

\subsection{Pengaruh Pupuk Anorganik NPK, Pupuk Organonitrofos dan Kombinasinya terhadap Karbon Terangkut pada Tanaman Tebu}

Tabel 6 menunjukkan bahwa perlakuan $\mathrm{C}$ $(100 \% \mathrm{NPK}+50 \%$ organonitrofos) menghasilkan karbon terangkut pada batang paling tinggi yaitu 9,84 $\mathrm{Mg} \mathrm{ha}^{-1}$ dan lebih tinggi 2,91 kali lebih besar dari tanpa pemupukan (perlakuan E), namun tidak berbeda nyata dengan karbon terangkut pada perlakuan A (100\% NPK), B $(100 \%$ organonitrofos), dan D (50\% NPK $+100 \%$ organonitrofos) yaitu 8,35 $\mathrm{Mg} \mathrm{ha}^{-1}, 7,93 \mathrm{Mg} \mathrm{ha}^{-1}$, $7,08 \mathrm{Mg} \mathrm{ha}^{-1}$. Kemudian karbon terangkut pada daun tertinggi dihasilkan pada perlakuan C $(100 \%$ NPK $+50 \%$ Organonitrofos), namun tidak berbeda nyata dengan perlakuan A (100\% NPK) dan D $(50 \%$ NPK $+100 \%$ Organonitrofos).

Karbon total terangkut tertinggi dihasilkan pada perlakuan C (100\% NPK $+50 \%$ Organonitrofos), namun tidak berbeda nyata dengan perlakuan $\mathrm{A}$ $(100 \%$ NPK $)$ dan D $(50 \%$ NPK $+100 \%$ Organonitrofos). Hasil ini menunjukkan bahwa pemberian $100 \%$ NPK yang dikombinasikan dengan

Tabel 5. Pengaruh Pupuk Anorganik NPK, Pupuk Organonitrofos dan Kombinasinya terhadap Bobot Kering Tanaman Tebu Ratoon 2.

\begin{tabular}{lrlrrl}
\hline \multirow{2}{*}{ Perlakuan } & \multicolumn{5}{c}{ Bobot Kering $\left(\mathrm{Mg} \mathrm{ha}^{-1}\right)$} \\
\cline { 2 - 6 } & \multicolumn{2}{c}{ Batang } & Daun & Total \\
\hline 100\% NPK & $22,41 \mathrm{bc}$ & $10,35 \mathrm{~b}$ & $32,76 \mathrm{bc}$ \\
100\% Organonitrofos & $17,53 \mathrm{~b}$ & $6,96 \mathrm{ab}$ & 24,49 & $\mathrm{~b}$ \\
$100 \%$ NPK + 50\% Organonitrofos & $29,40 \mathrm{bc}$ & $10,68 \mathrm{~b}$ & $40,08 \mathrm{c}$ \\
$50 \%$ NPK + 100\% Organonitrofos & $21,49 \mathrm{bc}$ & $7,18 \mathrm{~b}$ & 28,67 & $\mathrm{bc}$ \\
Tanpa Pemupukan & 8,21 & $\mathrm{a}$ & $3,19 \mathrm{a}$ & $11,40 \mathrm{a}$ \\
\hline BNT 5\% & 10,32 & 3,97 & 13,13 & \\
\hline
\end{tabular}

Keterangan: Angka yang diikuti oleh huruf yang berbeda pada kolom yang sama menunjukkan perbedaan yang nyata pada taraf $5 \%$ uji BNT. 
Tabel 6. Pengaruh Pupuk Anorganik NPK, Pupuk Organonitrofos dan Kombinasinya terhadap C Terangkut pada Tanaman Tebu.

\begin{tabular}{lccc}
\hline \multirow{2}{*}{ Perlakuan } & \multicolumn{3}{c}{ C terangkut $\left(\mathrm{Mg} \mathrm{ha}^{-1}\right)$} \\
\cline { 2 - 4 } & Batang & Daun & Total \\
\hline $100 \%$ NPK & $7,93 \mathrm{~b}$ & $3,98 \mathrm{c}$ & $11,92 \mathrm{bc}$ \\
$100 \%$ Organonitrofos & $7,08 \mathrm{~b}$ & $2,33 \mathrm{ab}$ & $9,41 \mathrm{~b}$ \\
$100 \%$ NPK + 50\% Organonitrofos & $9,84 \mathrm{~b}$ & $4,44 \mathrm{c}$ & $14,28 \mathrm{bc}$ \\
$50 \%$ NPK + 100\% Organonitrofos & $8,35 \mathrm{~b}$ & $2,54 \mathrm{bc}$ & $10,89 \mathrm{bc}$ \\
Tanpa Pemupukan & $3,38 \mathrm{a}$ & $0,88 \mathrm{a}$ & $4,26 \mathrm{a}$ \\
\hline \multicolumn{1}{c}{ BNT 5\% } & 3,44 & 1,56 & 4,71
\end{tabular}

Keterangan: Angka yang diikuti oleh huruf yang berbeda pada kolom yang sama menunjukkan perbedaan yang nyata pada taraf $5 \%$ uji BNT.

pupuk Organonitrofos 50\% dapat meningkatkan karbon terangkut pada daun, batang, dan total tanaman tebu ratoon 2 serta dapat memenuhi kebutuhan hara tanaman tebu secara optimal. Hal ini sesuai dengan hasil penelitian Amalia (2017) yang menyatakan bahwa pemberian $100 \% \mathrm{NPK}+50 \%$ Organonitrofos menghasilkan karbon terangkut paling tinggi pada daun, batang, dan total tanaman tebu plant cane di tanah Ultisol dibandingkan perlakuan lainnya. Kemudian hal tersebut juga didukung hasil penelitian Nurhidayat (2018) yang menunjukkan bahwa kombinasi $100 \%$ pupuk NPK dengan $50 \%$ pupuk Organonitrofos menghasilkan karbon terangkut tertinggi pada daun, batang, dan total tanaman tebu ratoon 1 di tanah Ultisol yaitu sebesar 12,48 $\mathrm{Mg} \mathrm{ha}^{-1}$, 2,95 $\mathrm{Mg} \mathrm{ha}^{-1}$, dan 15,43 $\mathrm{Mg} \mathrm{ha}^{-1}$. Kandungan karbon pada tanaman tebu cukup tinggi khususnya pada batang tebu. Karbon berperan penting dalam pembentukan bahan organik, dimana sekitar $47 \%$ dari bobot kering tanaman adalah karbon (Utomo, dkk., 2016).

\subsection{Pengaruh Pupuk Anorganik NPK, Pupuk Organonitrofos dan Kombinasinya terhadap Nitrogen Terangkut pada Tanaman Tebu}

Data pada Tabel 7 menunjukkan bahwa perlakuan C (100\% NPK $+50 \%$ Organonitrofos) menghasilkan serapan hara nitrogen pada batang paling tinggi tetapi tidak berbeda nyata dengan perlakuan A (100\% NPK) dan D (50\% NPK + $100 \%$ Organonitrofos). Kemudian serapan hara nitrogen pada batang paling rendah terdapat pada perlakuan E (tanpa pemupukan), namun tidak berbeda nyata dengan perlakuan B (100\% Organonitrofos). Serapan hara nitrogen pada daun tertinggi terdapat pada perlakuan C $(100 \%$ NPK
$+50 \%$ Organonitrofos) tetapi tidak berbeda nyata pada perlakuan A ( $100 \%$ NPK) dan D (50 \% NPK $+100 \%$ Organonitrofos). Perlakuan E (tanpa pemupukan) menghasilkan serapan $\mathrm{N}$ pada daun paling rendah dan berbeda nyata dengan perlakuan pemupukan.

Total nitrogen terangkut pada perlakuan $\mathrm{C}$ $(100 \% \mathrm{NPK}+50 \%$ Organonitrofos) menunjukkan hasil yang tertinggi, namun tidak berbeda nyata dengan perlakuan A (100\% NPK). Sedangkan untuk total serapan N pada perlakuan A $(100 \%$ NPK), B (100\% Organonitrofos), dan D (50\% NPK $+100 \%$ Organonitrofos) tidak berbeda nyata dan perlakuan E (tanpa pemupukan) menghasilkan serapan Nitrogen terendah. Hal ini menunjukkan bahwa pemberian pupuk anorganik 100\% NPK yang dikombinasikan dengan 50\% Organonitrofos memberikan pengaruh yang sama terhadap serapan $\mathrm{N}$ oleh tanaman tebu dengan perlakuan $100 \%$ NPK.

Hasil penelitian Amalia (2017) menunjukkan bahwa perlakuan $100 \%$ NPK yang dikombinasikan dengan $50 \%$ organonitrofos menghasilkan total $\mathrm{N}$ terangkut tanaman tebu plant cane paling tinggi dan tidak berbeda nyata dengan perlakuan $100 \%$ NPK. Hal tersebut juga didukung oleh hasil penelitian Nurhidayat (2018) yang menunjukkan bahwa total $\mathrm{N}$ terangkut pada tanaman tebu ratoon 1 paling tinggi terdapat pada perlakuan kombinasi $100 \%$ NPK $+50 \%$ orgnonitrofos, tetapi tidak berbeda nyata dengan perlakuan $100 \%$ NPK , dan $50 \%$ NPK $+100 \%$ orgnonitrofos.

\subsection{Pengaruh Pupuk Anorganik NPK, Pupuk Organonitrofos dan Kombinasinya terhadap Fosfor Terangkut pada Tanaman Tebu}

Tabel 8 menunjukkan bahwa perlakuan D $(50 \% \mathrm{NPK}+100 \%$ Organonitrofos) menghasilkan 
Tabel 7. Pengaruh Pupuk Anorganik NPK, Pupuk Organonitrofos dan Kombinasinya terhadap N Terangkut pada Tanaman Tebu.

\begin{tabular}{lcrrr}
\hline \multirow{2}{*}{ Perlakuan } & \multicolumn{4}{c}{$\mathrm{N}$ terangkut $\left(\mathrm{kg} \mathrm{ha}^{-1}\right)$} \\
\cline { 2 - 5 } & Batang & Daun & Total \\
\hline 100\% NPK & $188,24 \mathrm{bc}$ & $149,68 \mathrm{c}$ & 337,92 & $\mathrm{bc}$ \\
$100 \%$ Organonitrofos & $122,72 \mathrm{ab}$ & $10,88 \mathrm{~b}$ & 226,60 & $\mathrm{~b}$ \\
$100 \%$ NPK + 50\% Organonitrofos & $260,70 \mathrm{c}$ & $189,69 \mathrm{c}$ & $430,15 \mathrm{c}$ \\
$50 \%$ NPK + 100\% Organonitrofos & $200,60 \mathrm{c}$ & $120,58 \mathrm{bc}$ & $321,18 \mathrm{~b}$ \\
Tanpa Pemupukan & $49,79 \mathrm{a}$ & $35,75 \mathrm{a}$ & 85,54 & $\mathrm{a}$ \\
\hline \multicolumn{1}{c}{ BNT 5\% } & 74,48 & 41,81 & 130,53 & \\
\hline
\end{tabular}

Keterangan: Angka yang diikuti oleh huruf yang berbeda pada kolom yang sama menunjukkan perbedaan yang nyata pada taraf $5 \%$ uji BNT.

Tabel 8. Pengaruh Pupuk Anorganik NPK, Pupuk Organonitrofos dan Kombinasinya terhadap PTerangkut pada Tanaman Tebu

\begin{tabular}{lrrrrr}
\hline \multirow{2}{*}{ Perlakuan } & \multicolumn{5}{c}{ P terangkut $\left(\mathrm{kg} \mathrm{ha}^{-1}\right)$} \\
\cline { 2 - 6 } & \multicolumn{2}{c}{ Batang } & Daun & Total \\
\hline 100\% NPK & 25,05 & $\mathrm{bc}$ & $15,95 \mathrm{c}$ & 41,00 & $\mathrm{c}$ \\
100\% Organonitrofos & 15,05 & $\mathrm{~b}$ & $8,42 \mathrm{ab}$ & 23,48 & $\mathrm{~b}$ \\
$100 \%$ NPK + 50\% Organonitrofos & 27,92 & $\mathrm{c}$ & $15,68 \mathrm{c}$ & 43,60 & $\mathrm{c}$ \\
$50 \%$ NPK + 100\% Organonitrofos & 32,07 & $\mathrm{c}$ & $12,43 \mathrm{bc}$ & 44,50 & $\mathrm{c}$ \\
Tanpa Pemupukan & 1,03 & $\mathrm{a}$ & $2,65 \mathrm{a}$ & 3,68 & $\mathrm{a}$ \\
\hline \multicolumn{1}{c}{ BNT 5\% } & 9,56 & 5,94 & 14,68 & \\
\hline
\end{tabular}

Keterangan: Angka yang diikuti oleh huruf yang berbeda pada kolom yang sama menunjukkan perbedaan yang nyata pada taraf $5 \%$ uji BNT.

serapan $\mathrm{P}$ paling tinggi pada batang, tetapi tidak berbeda nyata dengan perlakuan A (100\% NPK) dan C (100\% NPK + $50 \%$ Organonitrofos). Sedangkan serapan $\mathrm{P}$ paling tinggi pada daun terdapat pada perlakuan A (100\% NPK) walaupun tidak berbeda nyata dengan perlakuan C (100\% NPK $+50 \%$ Organonitrofos), dan D (50\% NPK + $100 \%$ Organonitrofos).

Total fosfor terangkut tertinggi terdapat pada perlakuan D (50\% NPK + 100\% Organonitrofos) tetapi tidak berbeda nyata dengan perlakuan A (100\% NPK), dan C $(100 \%$ NPK $+50 \%$ Organonitrofos). Hal ini menunjukkan bahwa 50\% pupuk anorganik NPK yang dikombinasikan dengan $100 \%$ Organonitrofos memberikan pengaruh yang sama terhadap serapan P pada batang, daun dan total tanaman tebu dengan perlakuan kombinasi $100 \%$ NPK $+50 \%$ Organonitrofos dan $100 \%$ NPK. Hal ini sesuai dengan hasil penelitian Satgada (2017) yang menunjukan bahwa kombinasi $100 \%$ NPK $+50 \%$ Organonitrofos, $50 \%$ NPK $+100 \%$ Organonitrofos, dan $100 \%$ NPK menghasilkan fosfor terangkut pada batang dan total tanaman tebu plant cane yang lebih tinggi dibandingkan dengan hanya menggunakan $100 \%$ Organonitrofos dan tanpa pemupukan. Hal tersebut juga didukung oleh hasil penelitian Nurhidayat (2018) yang menyatakan bahwa $100 \%$ NPK, kombinasi $100 \%$ NPK $+50 \%$ Organonitrofos, dan $50 \%$ NPK yang dikombinasikan dengan $100 \%$ organonitrofos menghasilkan fosfor terangkut tanaman tebu ratoon 1 lebih tinggi daripada hanya menggunakan $100 \%$ organonitrofos dan tanpa pemupukan.

\subsection{Hubungan antara Kandungan Hara $\mathrm{N}$ dan $P$ di dalam Tanah dan Serapan Hara $N$ dan P Tanaman Tebu}

Hasil uji korelasi menunjukan bahwa kandungan $\mathrm{N}$-total tanah berkorelasi positif dan nyata terhadap total serapan $\mathrm{N}$ tanaman tebu ratoon 2 di tanah Ultisol $(\mathrm{r}=0,90$; Tabel 9). Hal ini menunjukkan bahwa pemberian pupuk anorganik NPK dan pupuk organonitrofos atau kombinasinya mampu meningkatkan N-total tanah. Apabila kandungan $\mathrm{N}$-total tanah meningkat maka serapan $\mathrm{N}$ oleh tanaman juga akan meningkat. Hasil penelitian Nurhidayat (2018) juga menunjukan bahwa N-total tanah berkorelasi positif dan nyata terhadap total serapan $\mathrm{N}$ tanaman tebu ratoon 1 . 
Tabel 9. Hasil Uji Korelasi Antara N-Total Tanah, Dan P-Tersedia Tanah Dengan Total Serapan N, Dan P Tanaman Tebu Ratoon 2.

\begin{tabular}{lll}
\hline Uji korelasi & \multicolumn{1}{c}{ Persamaan } & $\mathrm{r}$ \\
\hline N-total dengan N terangkut & $\mathrm{y}=-296,212+2719,29 \mathrm{x}$ & $0,900^{* *}$ \\
P-tersedia dengan P terangkut & $\mathrm{y}=-25,826+7,5281 \mathrm{x}$ & $0,978^{*}$ \\
\hline
\end{tabular}

Keterangan : $*=$ nyata pada taraf $5 \%, * *=$ nyata pada taraf $1 \%$ dan $\mathrm{r}=$ koefisien korelasi.

Tabel 9 menunjukan bahwa pupuk anorganik NPK, organonitrofos dan kombinasinya mampu meningkatkan serapan $\mathrm{P}$ pada tanaman tebu ratoon 2 . Hal tersebut dapat dilihat pada hubungan $\mathrm{P}$ tersedia di dalam tanah yang berkorelasi positif sangat nyata terhadap serapan $\mathrm{P}$ tanaman tebu ratoon 2 di tanah Ultisol $(\mathrm{r}=0,978$; Tabel 9). Hasil penelitian Satgada (2017) juga menunjukan bahwa P-tersedia di dalam tanah berkorelasi positif dan sangat nyata terhadap $P$ terangkut oleh tanaman tebu plant cane di tanah Ultisol. Hal tersebut juga didukung oleh hasil penelitian Nurhidayat (2018) yang menunjukan bahwa P-tersedia tanah berkorelasi positif terhadap $\mathrm{P}$ terangkut tanaman tebu ratoon 1 di tanah Ultisol.

\section{KESIMPULAN}

Pemberian pupuk anorganik NPK, pupuk organonitrofos dan kombinasinya berpengaruh nyata terhadap produksi dan hara terangkut $\mathrm{C}, \mathrm{N}, \mathrm{P}$ tanaman tebu ratoon 2, namun tidak berpengaruh nyata terhadap populasi tanaman tebu ratoon 2 . Selanjutnya, pemberian $100 \%$ NPK, 50\% NPK + $100 \%$ Organonitrofos, $100 \%$ NPK $+50 \%$ Organonitrofos memberikan produksi dan hara terangkut $\mathrm{C}, \mathrm{N}, \mathrm{P}$ tanaman tebu yang tidak berbeda nyata, namun nyata lebih tinggi dibandingkan dengan perlakuan $100 \%$ Organonitrofos dan tanpa pemupukan. Di samping itu, terdapat korelasi positif antara N-total tanah dan P-tersedia tanah dengan $\mathrm{N}$ dan $\mathrm{P}$ yang diserap oleh tanaman tebu ratoon 2 , sehingga kandungan $\mathrm{N}$-total tanah dan P-tersedia tanah menentukan jumlah $\mathrm{N}$ dan $\mathrm{P}$ yang dapat diserap oleh tanaman tebu ratoon 2 .

\section{UCAPAN TERIMA KASIH}

Penulis mengucapkan terimakasih kepada Prof. Ir. Jamalam Lumbanraja, Ph.D. yang telah membimbing, mendanai dan memfasilitasi penelitian ini. Serta Dr. Supriatin, S.P., M.Sc. yang telah memberikan bimbingan kepada penulis.

\section{DAFTAR PUSTAKA}

Agustina, W. 2017. Pengaruh Pupuk Organonitrofos dan Kombinasinya dengan Pupuk Anorganik terhadap Perilaku Pertukaran Kalium dalam Tanah, serta Serapan K oleh Tanaman Tebu (Saccharum officinarum L.) di Tanah Ultisol Gedung Meneng. Skripsi. Universitas Lampung. Bandar Lampung. $78 \mathrm{hlm}$.

Amalia, R.H. 2017. Hubungan Perilaku Jerapan dan Ketersediaan Fosfor dalam Tanah dengan P-Terangkut oleh Tanaman Tebu (Saccharum officinarum L.) Akibat Perlakuan Pupuk Organonitrofos dan NPK di Tanah Ultisol Gedung Meneng. Skripsi. Universitas Lampung. Bandar Lampung. $71 \mathrm{hlm}$.

Direktorat Jenderal Perkebunan. 2017. Statistik Perkebunan Indonesia Komoditas Tebu. Direktorat Jenderal Perkebunan. Departemen Pertanian. $40 \mathrm{hlm}$.

Hardjowigeno, S. 2003. Klasifikasi Tanah dan Pedogenesis. Akademika Pressindo. Jakarta. $250 \mathrm{hlm}$.

Loks, N.A., W.Maggoel, J.W. Daar, D. Mamzing, and B.W. Seltim. 2014. The Effects of Fertilizer Residues in Soils and Crop Performance in Northern Nigeria : A review. J. Agric. Sci. Soil Sci. 4(9) : 180-184

Nugroho, S. G., Dermiyati, J. Lumbanraja, S. Triyono, H. Ismono, Y. T. Sari, dan E. Ayuandari. 2012. Optimun Ratio of Fresh Manure and Grain Size of Phosphate Rock Mixture in a Formulated Compost for Organomineral NP Fertilizer. Journal of Tropical Soils. 17(2):121-128.

Nurhidayat. 2018. Pengaruh Pupuk NPK, Pupuk Organonitrofos dan Kombinasinya terhadap Pertumbuhan, Produksi dan Serapan Hara Tanaman Tebu (Saccharum officinarum L.) Ratoon 1. Skripsi. Universitas Lampung. Bandar Lampung. $44 \mathrm{hlm}$.

Reijntjes, C., B. Haverkort, and A. W. Bayer.1992. Farming for the Future: An Introduction 
to Low-External-Input and Sustainable Agriculture. Macmillan Publisher. USA. $250 \mathrm{hlm}$.

Satgada, C.P. 2017. Hubungan Perilaku Jerapan dan Ketersediaan Fosfor dalam Tanah dengan P-Terangkut oleh Tanaman Tebu (Saccharum Officinarum L.) Akibat Perlakuan Pupuk Organonitrofos dan NPK di Tanah Ultisol Gedung Meneng. Skripsi. Universitas Lampung. Bandar Lampung. $69 \mathrm{hlm}$

Thom, W.O. dan M. Utomo. 1991. Manajemen Laboratorium dan Metode Analisis Tanah dan Tanaman. Penerbit Universitas Lampung. Bandar Lampung. $85 \mathrm{hlm}$.
Utami, S.N.H. and S. Handayani. 2003. Chemical properties in organic and conventional farming system. Jurnal Ilmu Pertanian. 10(2): 63-69.

Utomo. M., Sudarsono, B. Rusman, T. Sabrina, J. Lumbanraja, dan Wawan. 2016. Ilmu Tanah Dasar-dasar dan Pengelolaan. Prenada Media. Jakarta. $429 \mathrm{hlm}$.

Zulkarnain, E., R. Evizal, J. Lumbanraja, M. V. Rini, C. P. Satgada, W. Agustina, H. R. Amalia, dan T. R. Awang. 2017. Pupuk Anorganik dan Organonitrofos pada Tebu (Saccharum officinarum L.) di Lahan Kering Gedung Meneng. Jurnal Penelitian Pertanian Terapan. 17 (1): 77-88. 